\title{
Behandling uten samtykke
}

Helsehjelp er frivillig. Forutsetninger er at pasienten forstår hvorfor hjelpen ytes, hva den består av og konsekvensene av at den gis. Derfor krever man i utgangspunktet pasientens samtykke. Et gyldig samtykke kan være stilltiende, muntlig eller skriftlig, avhengig av prosedyrens eller tilbudets karakter, og kan spenne fra registreringen av et nikk ved starten av en fysisk undersøkelse til en tidkrevende samtale som setter legens respekt for pasientens autonomi på prøve.

Kjell Martin Moksnes har i dette nummer av Tidsskriftet tatt opp samtykkeproblematikk ved elektrokonvulsiv behandling (ECT) (1). Ved denne behandlingen ledes strøm gjennom hodet i 2-4 sekunder. Dette stimulerer hjernen og følges av muskelbevegelser som varer i opptil 60 sekunder. En vanligere betegnelse blant legfolk - men også helsepersonell - er elektrosjokk. Betegnelsen «sjokk» stammer fra den tid behandlingen ble gitt uten anestesi og kunne være ledsaget av kraftige kramper og endog skjelettskader. Den kom derfor i miskreditt. Filmen Gjøkeredet, med glimrende skuespillerprestasjon av Jack Nicholson, bidro også til det negative omdømmet. Mediesynsere uten medisinsk innsikt fortsetter å omtale behandlingen på linje med lobotomi til tross for at den har gjennomgått mange tekniske modifikasjoner gjennom bruk av kortvarig narkose, muskelavslappende medikamenter for å redusere rykninger og forbedringer i måten strømmen gis på. Modifikasjonene har redusert bivirkningene dramatisk (2).

Det er 75 år siden man begynte å gi elektrokonvulsiv behandling ved psykiske lidelser - ukritisk de første årene, noe som må ses på bakgrunn av mangelen på annen effektiv behandling. I dag er det bred enighet om nytten ved livstruende depresjoner der annen behandling svikter (3). Anvendelsen på denne indikasjon opprettholdes til tross for dokumentasjon av langtidseffekter på visse nevropsykologiske funksjoner (4). Det faktum at vi fortsatt ikke forstår hvordan behandlingen virker, bør også mane til forsiktighet. Klart kritiske røster til bruken ved alvorlig depresjon kan også noteres (5).

Når situasjonen er kritisk og behandling etter beste skjønn bør startes, må pasientens eventuelle nei til behandling veies opp mot den plikt helsepersonell har til å gi hjelp. Tvang kan da bli aktuelt, men må alltid hjemles i lov. Hyppigst skjer det med hjemmel i loven om psykisk helsevern, i pasient- og brukerrettighetsloven og i helsepersonelloven. Den første hjemler imidlertid ikke elektrokonvulsiv behandling, som oppfattes som et betydelig inngrep i pasientens autonomi. Siste utvei er da nødrettsparagrafen i straffeloven. Hvis behandlingen gis på dette grunnlag, er lovens krav at tilstanden ikke kan avhjelpes på annen måte og at faren som avverges, må være vesentlig større enn den skade som måtte forvoldes ved inngrepet.

Praksis, resultater og konsekvenser av å yte behandling mot pasientens ønske er særs viktig å diskutere i et rettssamfunn. Moksnes har konsentrert seg om sju pasienter som fikk behandlingen på tross av at det er dokumentert at de ikke ønsket den. Det gjøres overbevisende rede for at disse sju fylte de formelle kriterier som kreves for at legen kan gjøre bruk av nødrett. De ble raskt bedre - median levetid etter behandlingen var ni år. Men hva forteller Moksnes' materiale om villigheten til å gjennomgå ECT-behandling i de 234 øvrige seriene gitt til 134 pasienter? Her er vi på usikker grunn, hvilket Moksnes åpent erkjenner.

Vi vet ikke hvor mange som ble bedt om samtykke. Det var først i 1984 at helsemyndighetene innskjerpet at man skulle innhente pasientens samtykke ved ECT-behandling. Moksnes' materiale går tilbake til 1960-årene, og det er grunn til å anta at legene tidligere i mindre grad mente de trengte pasientens eksplisitte ja. For det annet har Moksnes bare hatt anledning til å vurdere pasientenes holdninger i de tilfeller der legen journalførte at pasienten var spurt. Faktisk har det ikke vært krevd skriftlig nedtegnelse av svaret før i de siste tiår og da eksplisitt bare i de tilfeller der behandlingen ble gitt uten samtykke. Derfor kan det i totalmaterialet være atskillig flere som fikk elektrokonvulsiv behandling på tross av at de ikke samtykket. En antydning om omfanget får man gjennom opplysningen om at blant de 18 som fikk behandlingen i første serie på vital indikasjon, var det fem som samtykket, seks der samtykke ikke er dokumentert, mens de resterende sju altså avslo. Hvis vi kan anta at disse uavklarte pasientene ikke atskilte seg vesentlig fra de sju som er dokumentert, har det sannsynligvis ikke skjedd mye kritikkverdig, men strengt tatt vet vi ikke det.

Det mest kritiske spørsmålet forblir ubesvart. Var samtykket informert, frivillig og uttrykkelig? Var informasjonen som ble gitt avpasset til pasienten slik at han/hun forsto hva som skulle skje? Var samtykket frivillig? Hvor reell var muligheten til å nekte og hvor ofte og i hvilket omfang ble overtalelser brukt? Moksnes er opptatt av dette og opplyser megetsigende at i første ECT-serie med 141 pasienter var det 21 som vegret seg, «men samtykket senere etter mer informasjon og fornyede anbefalinger». Hvor mange var samtykkekompetente? Moksnes gir eksempler på pasientuttalelser som etterlater inntrykk av at det må ha vært meget komplisert å konkludere om de faktisk var det. Alt i alt er det vanskelig å utelukke at det blant de samtykkende var flere som fikk elektrokonvulsiv behandling på usikker eller feil indikasjon - og kanskje for tidlig?

Med såpass mange ubesvarte spørsmål bør denne viktige studien lede til at det igangsettes en bred prospektiv undersøkelse av så vel indikasjonen for elektrokonvulsiv behandling som kvaliteten på det samtykket som innhentes - og det videre forløp.

\section{Stein A. Evensen \\ s.a.evensen@medisin.uio.no}

Stein A. Evensen (f.1942) er professor emeritus ved Universitetet i Oslo og tidligere overlege ved avdeling for blodsykdommer, Oslo universitetssykehus, Rikshospitalet.

Forfatter har fylt ut ICMJE-skjemaet og oppgir ingen interessekonflikter.

\section{Litteratur}

1. Moksnes KM. Elektrokonvulsiv terapi uten samtykke. Tidsskr Nor Legeforen 2013; 133: 2047-50.

2. Kellner C. Overview of electroconvulsive therapy (ECT) for adults. UpToDate. March 31, 2013. www.uptodate.com (29.9.2013).

3. American Psychiatric Association Committee on Electroconvulsive therapy. The practice of electroconvulsive therapy. Recommendations for treatment, training, and privileging. 2. utg. Washington D.C.: American Psychiatric Association, 2001.

4. Sackeim HA, Prudic J, Fuller R et al. The cognitive effects of electroconvulsive therapy in community settings. Neuropsychopharmacology 2007; 32: 244-54.

5. Fosse R, Read J, Bentall R. Elektrokonvulsiv behandling ved alvorlig depresjon: i konflikt med den Hippokratiske eden? Tidsskrift for Norsk psykologforening 2011 ; 48: $1160-71$ 